\title{
STATE TRADING AND INTERNATIONAL ORGANIZATION
}

\author{
J. E. S. FAWCETT*
}

\section{INTRODUCTTON}

The amount of good and harm done by state trading is a matter of some disputeamong both politicians and economists. No attempt will be made to enter into this dispute in this study, which accepts as facts that state trading is, on the one hand, not in full harmony with the economic philosophy which underlies such international instruments as the General Agreement on Tariffs and Trade, while it is, on theother, an essential part of the commercial relations of Communist China, the Soviet. Union, and like-minded countries. The purpose of this study, then, is to review what has been done by countries which have sought through international organization to limit the effects of state trading seen to be harmful; to consider some of the working arrangements that have been made for state trading between the countries: of East Europe; and finally, to consider whether international organization can. control state trading as an element in East-West trade.

\section{I}

\section{InTERNational Organizational EFForts}

The international case against state trading might be put on the following. grounds: The state trader has a preference for bilateral agreements with importing. or supplying countries, and so removes an important segment of trade from the area of free competition. State trading also inhibits competition and distorts commerce and production by yielding an artificial and excessive protection to domestic suppliers and by inducing inflation of prices of commodities for which the state trader is known to be in the market. Furthermore, the exercise by a state trader of internal monopoly, whether complete or partial, tends to be contagious, since other countries seek the same means of competing with, or protecting themselves from, the state trader. Finally, state trading may also be used by one country as an in-. strument of pressure upon or control of the economic life of another.

It has long been recognized that, for some of the reasons just suggested, there is: a conflict between state trading and the most-favored-nation standard. The reciprocal grant of most-favored-nation treatment between a state-trading country and a privatetrading country can result in concessions being made wholly on the side of the private-trading country: for the state trader may buy the goods to which the mostfavored-nation privileges should attach in a third country against which it maintains

- B.A. 1935, Fellow of All Soul's College 1938, M.A. 1938, Oxford University. General Counsel International Monetary Fund. Assistant Legal Adviser, British Foreign Office, 1945-50. Editor, International and Comparative Law Quarterly, 1951-55. Contributor to legal publications. 
a high tariff and then, being itself an arm of the government, obtain a refund of the duties imposed; for this reason, the import of goods from the private-trading country in the state-trading country would not be materially increased by the adoption of reciprocal most-favored-nation treatment. ${ }^{1}$ A series of bilateral agreements, ${ }^{2}$ which began with the Soviet Union-Latvia Commercial Agreement, 1927, was marked by an effort to strengthen the most-fayored-nation clause in two ways: by a requirement that the Soviet Union purchase a fixed quantity of commodities over time, "a rough and ready way of attempting to put the relations between a free-enterprise and a state-trading country on an equitable basis"; ${ }^{3}$ and by the more insubstantial support of an undertaking that "so far as relates to the treatment accorded by each party to the trade with the other, they will be guided in regard to the purchase and sale of goods ... to the employment of shipping ... and all similar matters by commercial and financial considerations only. ...."4

Similar principles were embodied in the trade agreement of 1938 between the United Kingdom and the United States. Article VIII(r) provided that where a monopoly was established or exclusive trading privileges were given to an agency by either contracting party, then first, the commerce of the territories of the other "shall receive fair and equitable treatment in respect of the foreign purchases of such monopoly or agency" (principle of nondiscrimination); and second, "such monopoly or agency will, in making its foreign purchases of any article, be influenced solely by considerations, such as those of price, quality, marketability and terms of sale, which would ordinarily be taken into account by a private commercial enterprise interested solely in purchasing on the most favourable terms."

The first attempt to generalize these principles and give them a multilateral structure was made in the drafting of a charter for an International Trade Organization. A section of the Havana Charter, entitled "State Trading and Related Matters," was intended to subject import and export monopolies to a rule of nondiscrimination and fair commercial practice. Article twenty-nine used the concepts and much of the language already familiar in bilateral agreements: state enterprises were to conduct their trade "in a manner consistent with the general principles of non-

${ }^{1}$ See Domke \& Hazard, State Trading and the Most-Favored Nation Clause, 52 AM. J. INT'L L. 55 (1958).

2 Treaty of Commerce Between the Union of Soviet Socialist Republics and Latvia, June 2, r927, No. I59I, 68 L.N.T.S. 32I; Treaty of Guarantee and Neutrality With Protocol Between the Union of Soviet Socialist Republics and Persia, Oct. I, 1927, No. 2620, I12 L.N.T.S. 275; Commercial Agreement With the Union of Soviet Socialist Republics, July 13, I935, 49 Stat. 3805, E.A.S. No. 81 (effective July 13, 1935); Commercial Agreement With the Union of Soviet Socialist Republics, Aug. 6, 1937, 50 SrAT. 16I9, E.A.S. No. 105 (effective Aug. 6, 1937).

${ }^{3}$ Harri Hawkins, Commercial Treaties and Agreements 202 (I95I).

- Temporary Commercial Agreement Between the United Kingdom and the Union of Soviet Socialist Republics, April 16, 1930, No. 2340, I0I L.N.T.S. 409, 418 (denounced by the United Kingdom in 1934).

"Trade Agreement With the United Kingdom, Nov. I7, 1938, 54 Stat. r897, E.A.S. No. I64 (effective Dec. 24, I939).

${ }^{\circ}$ United Nations Conference on Trade and Employment, Final Act and the Havana Charter for an International Trade Organization, CMD. No. 7375, c. 4 , § D, arts. 29-32 (1948). 
discriminatory treatment prescribed in this Charter," and this was explained as requiring that

... such enterprises shall, having due regard to the other provisions of this Charter, make any such purchases or sales solely in accordance with commercial considerations, including price, quality, availability, marketability, transportation and other conditions of purchase or sale, and shall afford the enterprises of the other Member countries adequate opportunity, in accordance with customary business practice, to compete for participation in such purchases or sales.

There had been also much discussion at the Havana Conference of the possibility of using the device of fixed purchase undertakings by state traders, already favored in bilateral agreements. This would have taken the form of an undertaking by state traders to negotiate annual purchasing commitments with the private-trading countries. The idea was finally discarded as impracticable, and the Conference had to content itself with article thirty-one, optimistically entitled "Expansion of Trade." This would have required any members of the proposed International Trade Organization maintaining or authorizing an import or export monopoly to

... negotiate with such other Member or Members in the manner provided for under Article I7 in respect of tariffs, and subject to all the provisions of this Charter with respect to such tariff negotiations, with the object of achieving:

(a) In the case of an export monopoly, arrangements designed to limit or reduce any protection that might be afforded through the operation of the monopoly to domestic users of the monopolized product, or designed to assure exports of the monopolized product in adequate quantities at reasonable prices;

(b) in the case of an import monopoly, arrangements designed to limit or reduce any protection that might be afforded through the operation of the monopoly to domestic producers of the monopolized product, or designed to relax any limitation on imports. ...

The goal of negotiation was to be "the establishment of the maximum import duty that may be applied in respect of the product concerned," or "any other mutually satisfactory arrangement" if that were not feasible.

The maximum import duty was, in its turn, defined as

... the maximum margin by which the price charged by the import monopoly for the imported product (exclusive of internal taxes conforming to the provisions of Article I8, transportation, distribution and other expenses incident to the purchase, sale or further processing, and a reasonable margin of profit) may exceed the landed cost. ...

The Havana Charter did not include any definition of state trading or state enterprises, and section D ("State Trading and Related Matters"), from which the texts above are quoted, speaks indifferently of state enterprises and monopolies, though they are not necessarily the same thing, and makes a passing reference to "marketing boards, commissions and similar organisations." However, in chapter five ("Restrictive Business Practices"), the Charter defines the term "public commercial enterprise" as meaning ${ }^{8}$

?Id. art. 30.

Id. art. 54 . 
(i) agencies of governments in so far as they are engaged in trade, and

(ii) trading enterprises mainly or wholly owned by public authority provided the Member concerned declares that for the purposes of this Chapter it has effective control over or assumes responsibility for the enterprises. ...

Strictly, this definition is for the purposes of chapter five, but if the Charter provisions are taken as a whole, it seems reasonable to assume that the drafters understood a "state enterprise" to be any agency of government, or for which a government is responsible, engaged in purchases and sales on government account. ${ }^{8}$ However, it was recognized that, as in the field of state immunity, despite the difficulty of categorizing all governmental functions precisely, it was possible to give some sensible meaning to "governmenal use"; and article twenty-nine was not to apply to imports of products "for immediate or ultimate consumption in governmental use." Further, due regard was to be had to the fact that some monopolies are established for social, cultural, humanitarian, or revenue purposes. ${ }^{10}$

The Havana Charter never entered into force, but it has been necessary to review in some detail its provisions on state trading, since they have been carried over into the General Agreement on Tariffs and Trade (GATT).11 Article seventeen ("State Trading Enterprises"), in its original form, laid down the same rules as article twenty-nine of the Havana Charter, in almost identical language. Further, article II-4 forbade the operation of an import monopoly in such a way as "to afford protection on the average in excess of the amount" provided for in the schedule of tariff concessions or as otherwise agreed between the parties negotiating a concession.

These pious undertakings, hardly susceptible of control, seem to have had little or no impact on state-trading practices, and in 1954, the contracting parties to GATT appointed a working party to consider a number of proposals on state trading. Acting on its report, the contracting parties introduced amendments to GATT in 1955 which were accepted by all but five. An interpretative note was appended to article II-4 stating that, in the absence of special agreement, the provisions of this paragraph should be "applied in the light of the provisions of Article $3^{\text {r }}$ of the Havana Charter." Further, two paragraphs were added to article seventeen, requiring that the contracting parties be notified of all products subject to monopoly trading; that contracting parties operating an import monopoly on a product not the subject of concession in schedules inform the contracting parties, at the request of an interested country, of the import mark-up on such products; and that reports on the operation of monopolies be submitted to the contracting parties on request, in order that they may ascertain whether it conflicts with the provisions of GATT. A general exception from these requirements is made for the disclosure of confidential information

\footnotetext{
"Contrast the meaning given to "operated by a State" in the International Convention for the Unification of Certain Rules Relating to the Immunity of State-owned Vessels, April 10, 1926, arts. I and 3 , and Additional Protocol, May 24, 1934, art. I, No. 4062, 176 L.N.T.S. 199, where governmental and commercial service are sharply distinguished.

${ }^{10}$ United Nations Conference on Trade and Employment, supra note 6, art. $3 \mathrm{r}$ (b).

${ }^{11}$ 6I Stat. (5), (6) (1947), T.I.A.S. No. r70o (effective Jan. I, 1948).
} 
which would impede law enforcement, or be otherwise contrary to the public interest, or prejudice the legitimate interests of particular enterprises.

Finally, article eleven, through an interpretative note, makes the rules on quantitative restrictions applicable to state trading, so that a state monopoly may not limit the quantity of imports or exports, ${ }^{12}$ except as permitted by those rules.

In November 1958 , the contracting parties established a panel which was to examine, among other things, ${ }^{13}$

the notification sent to the Contracting Parties concerning the products imported to or exported from their territories by enterprises of the kind described in paragraph $I(a)$ of Article XVII, and to make practical suggestions to the CONTRACTING PARTIES with a view to improving the procedure for notifications under that Article.

From this, it appears that article seventeen, even as amended, has so far borne little fruit beyond "opportunities for negotiations and consultations between governments on the trading activities of State enterprises and of private undertakings enjoying exclusive or special privileges."14

Nevertheless, it may be useful to attempt a brief summary of these GATT provisions. They seek broadly to curb or eliminate two factors in state trading: undue protection of domestic producers, and trade discrimination.

Goods imported by a state trader may be subject to a tariff bound under GATT. If the state trader purchases all imports of a particular commodity, or a sufficient proportion to permit control of the price, it can, by reselling the imported goods at high prices, provide additional protection for domestic suppliers offering similar goods at lower prices. The benefit of the tariff binding to the foreign seller could then be nullified. The combined effect of articles II-4 and XVII-I seems to be: First, if the state-trading country collects ${ }^{15}$ the bound duty on the entry of the goods, it may not, on reselling them, increase the price above landed cost by more than a defined "import mark-up,"16 which is virtually identical with the "maximum import duty" defined in the Havana Charter. Second, there is no obligation upon state traders to negotiate on the margin of protection for domestic suppliers, as there was in article thirty-one of the Havana Charter. However, negotiation is recommended, and it is presumably this which is covered by the interpretative note to article II-4, that it must be applied "in the light of the provisions of Article 3I of the Havana Charter."

The rule of nondiscrimination by state traders, effectuated through the "commercial considerations" clause, seems of little more effect than a declaration of intent. For "any agency having a monopoly would be acting in conformity with, rather than

${ }^{19}$ Thus, going further than Havana Charter art. $3 \mathrm{I}(5)$, which covered only imports.

${ }^{13}$ Gatr, Contracting Parties, I3th Sess. I73 (Doc. No. SR. 13/17) (I958).

${ }^{24}$ Gatt, Commercial Policy, I957, at 67 (1958).

${ }^{26}$ If it does not, it may add the equivalent of the bound duty to the resale price.

${ }^{10}$ Interpretative note to the General Agreement on Tariffs and Trade art. XVII-4(b), supra note Ir. The paragraphs added in 1955 to the original art. XVII now require notification of import mark-ups to contracting parties. 
departing from, 'commercial principles' and would be buying 'in the market which happened to be the most advantageous in each particular case' if it carried out skilfully the practice of 'discriminatory monopsony." "17 Further, it is far more difficult to establish international supervision of the buying and selling practices of a statetrading country, where much may be done by administrative decision, than over its tariffs and quotas: GATT allows that "the charging by a state enterprise of different prices for its sales of a product in different markets is not precluded [for article seventeen] provided that such different prices are charged for commercial reasons to meet conditions of supply and demand in export markets." 18

In conclusion, the far more stringent provisions of the Rome Treaty ${ }^{10}$ establishing the European Economic Community should be noticed. Article 37(I) provides that

Member States shall progressively adjust any State monopolies of a commercial character in such a manner as will ensure the exclusion, at the date of the expiry of the transitional period [twelve years from January I, I959], of all discrimination between the nationals of Members States in regard to conditions of supply or marketing of goods.

The provisions of this Article shall apply to any body by means of which a Member State shall de jure or de facto either directly or indirectly control, direct or appreciably influence importation or exportation between Member States. These provisions shall apply also to monopolies assigned by the State.

New measures tending to limit the effect of this undertaking are prohibited, and the Commission is charged with supervision of the manner and timing of the adjustments to be made. Article ninety also brings within the reach of all the rules contained in the Treaty "public enterprises and enterprises to which [member-states] grant special or exclusive privilege." It remains to be seen how these treaty arrangements will evolve.

\section{II}

\section{Soviet-Bloc ArRangements}

We may now turn to review very briefly some of the steps to organize statetrading relations which have been taken by countries, which are members of the Council of Mutual Economic Aid, ${ }^{20}$ of General Conditions ${ }^{21}$ to be inserted in foreign trade contracts to cover "all deliveries of goods between foreign trade organizations and member countries." There is some doubt whether the adoption of these condi-

\footnotetext{
${ }^{17}$ Jacob Viner, Trade Relations Between Free-Market and Controlled Economies 75-76 (Leaguc of Nations Pub. No. 1943.II.A.4).

${ }^{18}$ Interpretative note to the General Agreement on Tariffs and Trade art. XVII-I, supra note II.

${ }^{19}$ Treaty Establishing the European Economic Community, March 25, 1957, No. 4300, 298 U.N.T.S. Ir, 29 (effective Jan. I, r958).

${ }^{20}$ The Council was established in 1949, and the present members are Albania, Bulgaria, Czechoslovakia, the German Democratic Republic, Poland, Rumania, and the Soviet Union.

${ }^{21}$ See Berman, Unification of Contract Clauses in Trade Between Member Countries of the Council for Mutual Economic Aid, 7 INT'L \& Comp. L. Q. 659 (I958). This article contains a translation of the General Conditions with a commentary.
} 
tions by a foreign trade organization is mandatory or simply recommended, but it seems that, in practice, they are likely to be extensively used. Some member-countries have ${ }^{22}$

laid down in their bilateral trade agreements that their foreign trade organizations will in their mutual business contracts make use solely of these general conditions but even in such cases, it is provided that the parties may, in certain circumstances, agree upon exceptions.

The General Conditions are highly practical in form and seem to be the fruit of state-trading experience. Of particular interest are:

Paragraph 9, which provides as follows:

If the buyer does not fulfill within the time stipulated in the contract any obligations for assuring the seller's production provided by the contract, or if the buyer subsequently changes data previously furnished by him, and if in connection with this there follow substantial difficulties for the seller, connected with production, then the seller shall have the right to adjust the time of delivery proportionately, though not longer than the time of delay on the buyer's part and of performance of the aforementioned obligation, and/or to demand compensation for the actual losses incurred in connection therewith. The seller shall be obliged to give the buyer timely notice of adjustment of the time of delivery. By provision for damages, this secures such advantages as long-term contracts have to give by way of stability of production.

Paragraph 22: There are established varying periods of guarantee in which the seller remains responsible for the quality and prescribed characteristics of goods delivered.

Paragraphs 35, 36: Payment is made by "the bank of the seller's country"; the bank then debits the account of the "bank of the buyer's country," and settlement is made through clearing agreements. The commercial counsellor of the embassy of the buyer's country, called the trade delegate, is the recipient of the documents to be presented by the seller for payment.

Paragraph 65: In cases of dispute, arbitration is preferred to access to the "general courts," their jurisdiction being excluded; and, in fact, each of the member-countries has a permanent foreign trade tribunal.

Paragraph 72: No rights or obligations under foreign trade contracts between these countries may be assigned without the consent of the other party. Professor Berman observes of the whole scheme that "it adapts the institutional framework and technique of capitalist trade to trade between state enterprises of planned economies."23

\footnotetext{
${ }^{22}$ Letter from the Czechoslovak Permanent Representative to United Nations to Professor Harold J. Berman. Id. at $66 \mathrm{r}$.

${ }^{23}$ Id. at $66_{4}$.
} 


\section{EAst-West Trade}

Nevertheless, the venture made in the Economic Commission for Europe "to subject to some form of international regime" trade between the state-trading countries of East Europe and other countries represented on the Commission has so far had little success. In 1956, the Soviet Union proposed an All-European Agreement on Economic Cooperation. ${ }^{24}$ This proposal was conceived on broad lines, but contemplated that the Agreement would, in particular, deal with "trade and international payments, transport and communication, credit and banking, insurance, shipping and the like." Two articles of the Soviet draft agreement particularly concern us here:

Article 5. The participating States shall on a reciprocal basis grant to each other unconditional and unrestricted most-favoured-nation treatment with regard to all matters of trade and shipping between them and with regard to the status of natural and legal persons conducting business on the territory of any participating State subject to the conditions under which such activity is authorised by the law of such State.

A Contracting Party shall not apply with regard to the import from, or export to, the territory of another party any limitations, prohibitions or formalities not applied in this regard to all participating States.

…

Article 7. In order to facilitate the exchange of goods and services in European trade, the participating States shall endeavour to use the method of multilateral settlements in their trade relations, and shall in particular instruct their central banks to take part in a multilateral compensation agreement prepared within the framework of the United Nations Economic Commission for Europe. ...

Comments on the draft agreement were received from the countries participating in the Commission, and they were, in general, conciliatory, but sceptical. Apart from the countries of East Europe, whose comments were characteristically brief and formal, pleading for the adoption of the Agreement, members of the Commission joined in criticizing the draft of articles five and seven on two main lines: First, there were already a number of international agreements and agencies in the field, which, if properly employed and directed, could achieve the ends proposed in the draft. Second, the differences in economic structure and policy between the countries of East Europe and the rest would inhibit the operation of article five and defeat its intent.

The United Kingdom said: $:^{25}$

It is not clear how in practice one country can be satisfied that "most-favoured-nation" treatment is being accorded fully and without discrimination by another country where trade is carried on entirely or mainly by State agencies. Where trade is mainly governed by long-term contracts moreover, the "most-favoured-nation" principle can only operate at infrequent intervals, and not continuously. It is also exceedingly difficult to determine

26 U.N. Doc. No. E/ECE/270, pt. I (I957).

${ }^{25}$ Observations of the Government of the United Kingdom, id. at 56-57. 
when an organisation in such a country is resorting to what are commonly held to be unfair trading practices, e.g. "dumping," because of the special difficulties of ascertaining costs of production, including material costs.

Certain proposals also clearly imply trading practices, such as long-term commercial contracts, and a rigid framework of bilateral trading agreements, to which Her Majesty's Government does not generally subscribe, believing them not to be conducive to the expansion of world trade on a non-discriminatory basis.

\section{The Netherlands observed $:^{26}$}

Another consequence of the essential differences between the various economic systems is that a particular provision or obligation in a treaty will, in many cases, have entirely different implications for one party as compared with another. A clear case of this nature is contained in Article 5. The granting of unconditional most-favoured-nation treatment in the fields of foreign trade, exchange rates, tariffs, etc., would be making a real concession as far as the Netherlands and countries with a similar economic system are concerned. On the other hand a most-favoured-nation clause obtained in such cases from countries where international commerce and the distribution of goods, etc., are subject to a system of state control, has in itself little practical value.

It is generally recognized that the most-favored-nation standard is largely ineffective in trade between state and private traders, and it is not altogether easy to account for the continued inclusion of a most-favored-nation clause in commercial agreements with state-trading countries. ${ }^{27}$ It is in the nature of state trading that the government practicing it has in its hands a single instrument of economic policy, unlike the complex strands of private trade with which other countries grapple. The state trader blocks or opens or redirects the channel of imports and exports as his general plan dictates; but, in other countries, where trade policy is kept as close as practicable to an ideal structure of free competition between private traders, it cannot be subjected to uniform control, and no reciprocity between the systems is possible. Both aim to achieve a universal division of labor $^{28}$ by methods which are mutually exclusive, and hardly adaptable to international rationalization.

${ }^{30}$ Observations of the Government of the Netherlands, id. at 38,39 .

${ }^{27}$ See Domke \& Hazard, supra note $\mathrm{x}$, at 66, suggesting, some answers.

${ }^{28} \mathrm{Sec}, e . g .$, the deliberate plan for industrial and agriculțural specialization within the East European bloc between 1959 and 1965 . Nove, Soviet Trade and Soviet. Aid, Lloyds Bank Review, Jan. 1959, p. 1. 